\title{
Effects of Osmopriming on Germination and Vigour Traits of Bersim Clover (Trifolium alexandrinum L.)
}

\author{
Hossein Reza ROUHI'), Reza Tavakkol AFSHARI'1), Seyed Amir \\ MOOSAVI ${ }^{2}$, Mohammad Hossain GHARINEH ${ }^{2}$ \\ 1) University of Tehran, Department of Agronomy and Plant Breeding; Iran; Agri_engineer62@yahoo.com \\ 2) Ramin Agriculture and NaturalResources University, Department of Agronomy and Plant Breeding, Ahvaz, Iran; amir.msa@gmail.com
}

\begin{abstract}
Previous studies suggested that fast and uniform germination is important for good crop establishment. The present study was conducted to investigate the possibility of increasing germination characteristics by seed priming techniques. An experiment was conducted with three replicates and two treatments including: 2 different priming duration ( 8 and 12 hours) and 6 osmotic potential of PEG 6000 solutions (-0.8, -1,-1.2,-1.4,-1.6 Mpa) and distilled water as a control group). The priming solutions were prepared using polyethylene glycol 6000 (PEG). Our results showed that the most effective osmotic potential in improving germination characteristics of Trifolium alexandrium is $-0.8 \mathrm{MPa}$ for 16 hours.
\end{abstract}

Keywords: osmopriming, seed germination, bersim clover, germination rate, root length, vigor index

\section{Introduction}

Bersim clover (Trifolium alexandrinum L.) is highly used as a forage crop during recent decades. Fast growth and the great final production of this crop make it a good option for farmers to use it as a fresh forage products (Shrestha et al., 1996; Musavi Aghdam, 1985; Khoshgoftar, 1992). The results of researches shows that good production highly depends on suitable sowing date, climate condition, soil fertility, shrub height, the number of harvests and variety. For example in North part of Iran, farmers usually planting this crop after harvesting rice and the rate of production exceeded to 55-70 t/ha (Zarrineh et al., 1985; Khoshgoftar, 1992). Regarding to the important rule of this plant in production cycle of dairy and protein substance, the rules in fertility preservation and the plant coverage of soil is one the another important roles of this crop in agricultural production ( $1^{\text {st }}$ national forage crops congress of Iran). So one of the most important research priorities in forage production is to choose suitable forage performance and production strategies. Seed germination could be known as important and consequent factors in seedling establishment via different conditions. Seed enhancement techniques, such as seed priming, can be useful in increasing the forage yield. In osmopriming treatment which is also known as osmoconditioning, seeds incubated in polyethylene glycol (PEG), sorbitol, mannitol solution and let to uptake water in order to primary metabolic activities of germination process is started and radicle emergence happen (Ashraf and Foolad, 2005). This tech- nique has been used in some vegetable seeds to increase the germination rate, total germination and seedling uniformity, mainly under unfavorable environmental conditions (Bradford et al., 1990; Ozbingol et al., 1998; Nascimento and Arago, 2004; Korkmaz, 2006). When the seeds were primed and sowing them in the field, they usually show faster and more uniform germination comparing to nonprimed seeds (Bourgne et al., 2000). Priming can increase the germination and growth of seedling under stressed conditions in sunflower seeds (Demir et al., 2006). The aim of this study is to increase germination percentage and seedling vigor of bersim seeds by osmopriming with PEG, and to define the optimal combination of PEG concentration and treatment time.

\section{Materials and methods}

This study was carried out in September 2008 at the Department of Agronomy, Faculty of Agriculture, University of Tehran, Iran. Bersim clover from Shahid Beheshti culture and industry of Dezful, which is commonly grown in Iran, was used as seed material. Germination and early seedling growth (7 days) of the cultivar were studied using distilled water (control) and under osmotic potentials of $-0.8,-1,-1.2,-1.4,-1.6 \mathrm{Mega}$ pascal (MPa), for polyethylene glycol (PEG 6000) (Michel and Kaufmann, 1973).

\section{Seed treatments}

For osmopriming, bersim seeds ( $5.5 \%$ seed moisture) were immersed in osmotic solution at $20^{\circ} \mathrm{C}$ for 8 and 16 
60

$\mathrm{h}$ under dark conditions. Thereafter, the seeds were rinsed with distilled water three times. The treated seeds were surface-dried and dried back to their original moisture content via experience at room temperature (about $21^{\circ} \mathrm{C}, 45 \%$ relative humidity) determined by changes in seed weight. Moisture content of untreated seeds (control, 5.5\% moisture content), osmoprimed treated seeds was equilibrated at room temperature for 24 hours.

\section{Germination tests}

Three replicates of 50 seeds were subjected to germination between double layered papers with $5 \mathrm{ml}$ of water in $9 \mathrm{~cm}$ Petri dishes. These Petri dishes contained seeds were put into sealed plastic bags to avoid moisture loss. Seeds were allowed to germinate at $20 \pm 1^{\circ} \mathrm{C}$ in the dark condition for 7 days (ISTA, 1996). Germination was considered finished when the radicles were $2 \mathrm{~mm}$ long. Germination percentage was recorded every $12 \mathrm{~h}$ for 7 days. Germination rate was calculated to assess the rate of germination (Ellis and Roberts, 1980). Seedling length, seedling dry weight and vigor indexes 1 and 2 (sign of multiplication germination percentage $\times$ seedling length and germination percentage $\times$ seedling dry weight respectively) were measured after the $7^{\text {th }}$ day.

\section{Statistical analysis}

The statistical analysis was performed in factorial design were the treatment $(6 \times 2)$ arranged in a randomized completely block design; with three replications and 50 seeds per replicate. The first factor was osmotic potential levels $(-0.8,-1.0,-1.2,-1.4,-1.6$ and $0 \mathrm{MPa}$ as a control group) (PEG) and the second, duration of seed priming ( 8 and 16 hours). Data for germination and abnormal germination percentage were subjected to arcsine transformation before analysis of variance was made using MSTAT-C program (Michigan State University). Mean separation was performed by Fisher's least significant difference (LSD) test if $\mathrm{F}$-test was significant at $(\mathrm{P}<0.05)$.

\section{Results and discussions}

The results of the experiment showed that, the priming duration, affects significantly the final germination percentage, the mean germination time and also the vigor index 2 (Tab. 1). In osmotic potential of osmopriming solution on investigated traits only seedling dry weight was insignificant (Tab. 1). Since the interaction effect of time in osmotic potential in osmopriming solution was significant, it was decided to avoid explaining and discussing about main effects so only interaction effects of time * potential on above mentioned traits was discussed and investigated.

\section{Final Germination Percentage (FGP)}

As it is shown in the Fig. 1, the highest germination percentage was seen in primed seeds for 8 hours with po-
Tab. 1. Analysis of evaluation variance of germination indexes of studied traits via osmopriming

\begin{tabular}{cccccccc}
\hline \multicolumn{7}{c}{ Mean of squares } \\
\hline SOV & df & FGP & MGT & SL & SDW & VI1 & VI2 \\
\hline Replication & 2 & 0.26 & 0.018 & 0.047 & 0.034 & 119.9 & .042 \\
Time & 1 & $48.16^{* *}$ & $53.05^{* *}$ & $0.025^{\text {ns }}$ & $0.018^{\text {ns }}$ & $25.52^{\text {ns }}$ & $0.05^{* *}$ \\
Potential & 5 & $31.92^{* *}$ & $77.1^{* *}$ & $2.9^{* *}$ & $0.086^{* *}$ & $685.5^{* *}$ & $0.058^{* *}$ \\
Time & 5 & $32.37^{* *}$ & $43.55^{* *}$ & $0.17^{* *}$ & $0.018^{\text {ns }}$ & $276.54^{* *}$ & $0.033^{* *}$ \\
Potential & 5 & & & & & & \\
Error & 22 & 0.26 & 0.033 & 0.014 & 0.055 & 247.7 & 0.0016 \\
\hline
\end{tabular}

$\mathrm{ns},{ }^{* *},{ }^{*}$ Respectively non significant and significant of 1 and 5 percent of probability

tential of -1.2 MPa comparing to other potentials and control group (Fig. 1). And regarding to the 16 hours time period of priming the highest rate was observed in the potential of - $0.8 \mathrm{MPa}$ in this time. It was reported that, osmopriming of watermelon seeds caused the decrease mean germination time and in contrast, increase percentage of germinated seeds (Demir and Van de Vanter, 1999). Most of researchers reported the positive effects of seed priming on seed germination percentage (Misra and Dwivedi, 1980; Chiu et al., 2002).

\section{Germination Rate}

Highest germination rate was observed in primed seed of $8 \mathrm{~h}$ at $-1.2 \mathrm{MPa}$ osmotic potentials (Fig. 2). Subedi and $\mathrm{Ma}$ (2005) reported that one of the most important conditions for crop potential performance is fast and uniform germination which is a resultant of priming seeds in the farm. Harris et al. (2001), Giri and Schilinger (2003) and Finch-Savage et al. (2004) reported that the seed priming have a positive effects on seed germination rate comparing to control.

\section{Seedling Length (SL)}

The highest length of seedling was observed in the same mentioned composition of priming treatments ( $8 \mathrm{~h}$ and -1.2MPa; $16 \mathrm{~h}$ and -0.8MPa) (Fig. 3). Basra et al. (1994) reported the increase of radicle and plumule growth of primed onion seeds in 7 days after sowing and the primary seedling growth. It was observed that seeds number and performance of each plant in prime seeds of chickpea (water and mannitol 4\%) was higher in comparison with nonprime seeds. This is the resultant of the increase of acid invertase activity in the apical of the main stem after sowing, because the availability of apical to hexsose, increased as the result of enzyme activity (Subedi and Ma, 2005).

\section{Seedling Dry Weight (SDW)} dry.

There was no significant effects of priming on seedling

\section{Vigour Index (1)}

Vigour index was higher in the primed seed with $-0.8 \mathrm{MPa}$ of PEG 6000 for $16 \mathrm{~h}$ was higher comparing with other treatments(Fig. 4). 


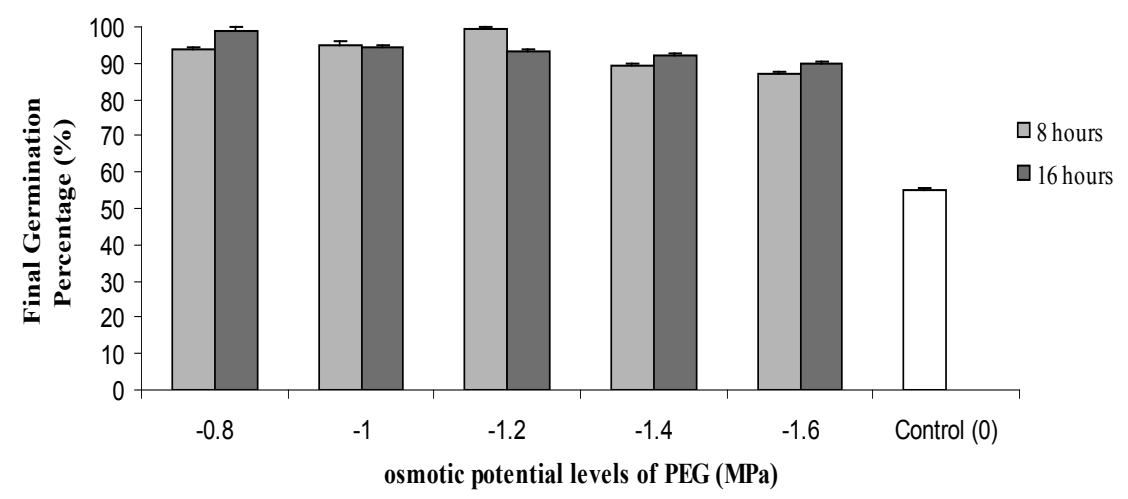

Fig. 1. Influence of osmotic potential levels of osmopriming treatments on the Final Germination Percentage (FGP) in Bersim Clover under 8 and 16 hours durations +S.E (Error bars indicate standard deviation from the mean). seed priming with $-0.8 \mathrm{MPa}$ PEG; -1 MPa PEG; -1.2 MPa PEG; -1.4 MPa PEG; -1.6 MPa PEG; seed priming with polyethylene glycol and 0MPa as a control group

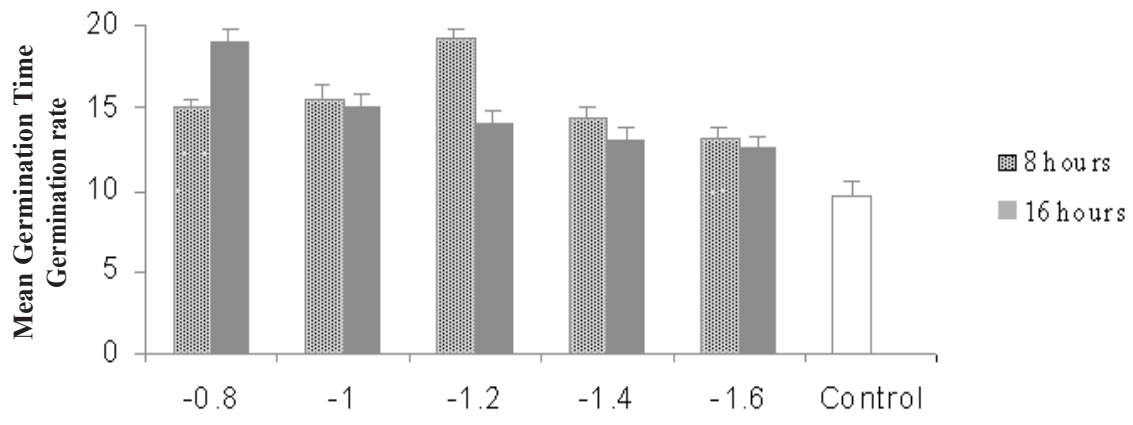

(0)

os motic potential levels of PEG (MPa)

Fig. 2. Influence of osmotic potential levels of osmopriming treatments on the Mean Germination Time (MGT) in Bersim Clover under 8 and 16 hours durations + S.E.

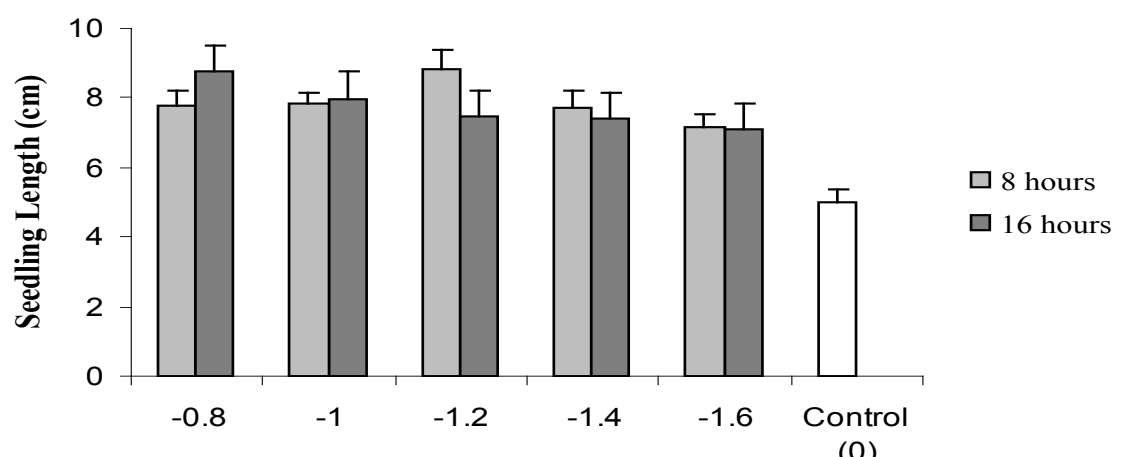

os motic potential levels of PEG (MPa)

Fig. 3.Influence of osmotic potential levels of osmopriming treatments on the Seedling Length (SL) in Bersim Clover under 8 and 16 hours durations + S.E.

Vigor Index (2)

The highest value for this index was observed in primed seed for $8 \mathrm{~h}$ in -1MPa osmotic potential (Fig 5).
Priming treatments significantly affected germination vigour of Bromus and hydropriming for 12 hour could increase seed vigour of Bromus (Tavili et al., 2010) 
62

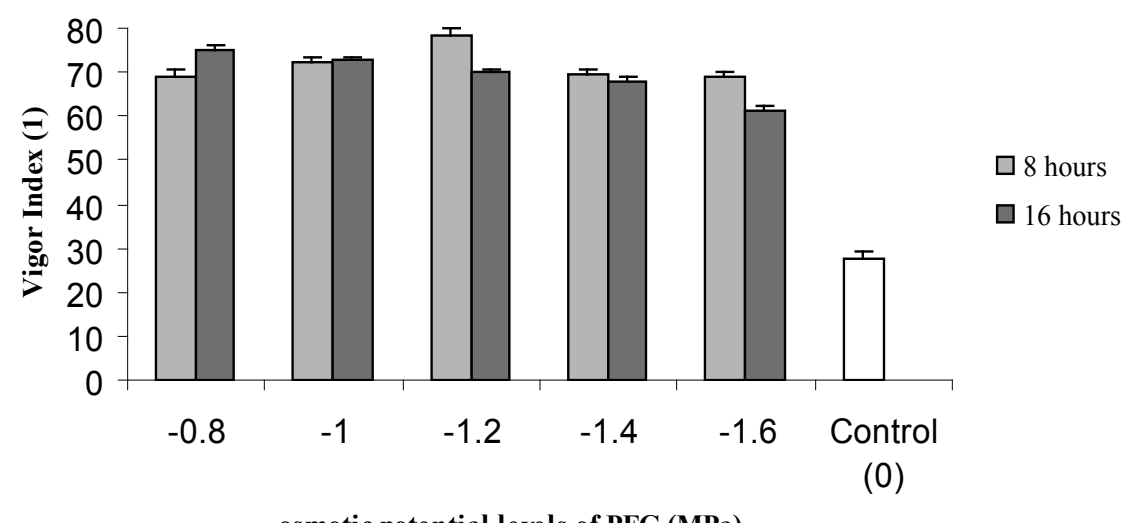

Fig. 4. Influence of osmotic potential levels of osmopriming treatments on the Vigour Index 1(VI1) in Bersim Clover under 8 and 16 hours durations + S.E.

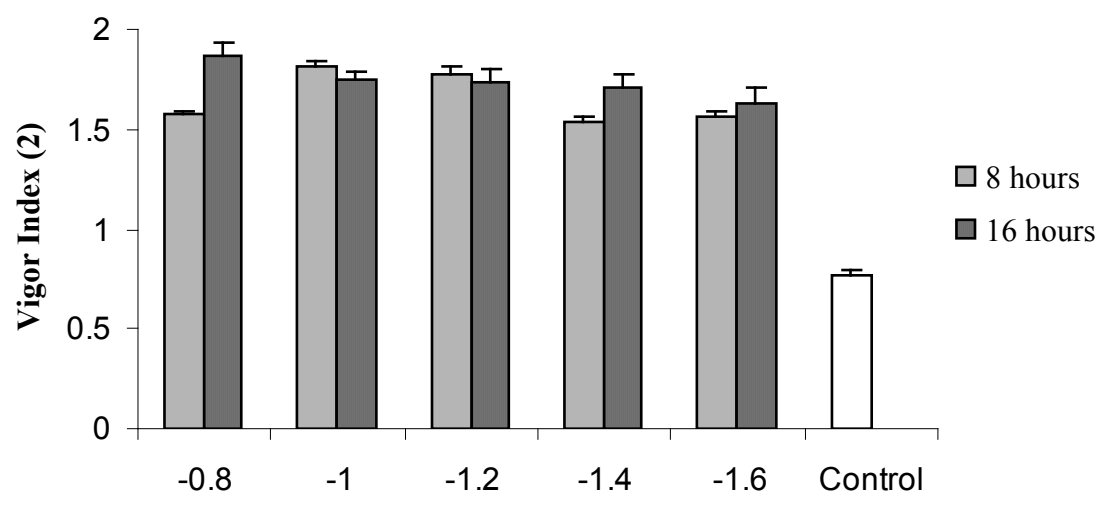

$(0)$

os motic potential levels of PEG (MPa)

Fig. 5. Influence of osmotic potential levels of osmopriming treatments on the Vigour Index 2(VI2) in Bersim Clover under 8 and 16 hours durations + S.E.

\section{Discussion and conclusions}

This study showed that the seed priming at $-0.8 \mathrm{MPa}$ for $16 \mathrm{~h}$ of duration and $-1.2 \mathrm{MPa}$ for $8 \mathrm{~h}$ of duration exhibited the highest value of the investigated traits in comparison with other treatments and control group. But the comparison of these two elite treatments shows that seed priming period $(16 \mathrm{~h})$ at $-0.8 \mathrm{MPa}$ potential of PEG solution could be selected as the final choose for seed priming of bersim clover. Akinola et al. (2000) reported that higher duration of exposure to seed treatment resulted in higher cumulative germination in wild sunflower and Caseiro et al. (2004) found that hydropriming was the most effective method for improving seed germination of onion, especially when the seeds were hydrated for $96 \mathrm{~h}$ compared to $48 \mathrm{~h}$. The present study revealed that PEG had no toxic effect since all seeds germinated. Mehra et al. (2003) and Michel (1983) indicated that PEG molecules do not enter to seed and Khajeh-Hosseini et al. (2003) found that there was no toxicity of PEG. Seed priming exhibited positive effects on germination characteristic of amaranth cultivars such as speed of germination and root length and antioxidant enzymes activities were increased due to seed prim- ing which could resulted in increasing tolerance of primed seeds to environmental stresses such as salinity (Moosavi et al., 2009). Finally it could be recommended that, the results of this study to be investigate in the farm condition in order to confirm the fulfilled experiments of this project.

\section{References}

Akinola, J. O., A. Larbi, G. O. Farinu and A. Odunsi (2000). Seed treatment methods and duration effects on germination of wild sunflower. Exp. Agric. 36:63-69.

Ashraf, M. and M. R. Foolad (2005). Pre-sowing seed treatment a shotgun approach to improve germination, plant growth, and crop yield under saline and non-saline conditions. Adv. Agron. 88:223-271.

Basra, A. S., B. Singh and C. P. Malik (1994). Amelioration of the effects ageing in onion seed by osmotic priming and associated changes in oxidatne metabolism. Biol. Plantarum. 36(3):365-371.

Bourgne, S., C. Job and D. Job (2000). Sugarbeet seed priming: Solubilization of the basic subunit of 11.S globulin in individual seeds. Seed Sci. Res. 10:153-161. 
Bradford, K. J., J. J. Steiner and S. E. Trawatha (1990). Seed priming influence on germination and emergence of pepper seed lots. Crop Sci. 30:718-721.

Cantliffe, D. J. (1991). Benzyladenine in the priming solution reduces thermodormancy of lettuce seeds. Hort. Technol. 1:95-97.

Caseiro, R., M. A. Bennett and J. Marcos-Filho (2004). Comparison of three priming techniques for onion seed lots differing in initial seed quality. Seed Sci. Technol. 32:365375.

Chiu, K. Y., and J.M. Sung (2002). Effect of priming temperature on storability of primed sh-2 sweet corn seed. Crop Sci. 42:1996-2003.

Demir. J. and H. A. Van de Venter (1999). The effect of priming treatments on the performance of watermelon Citrollus Lanatns (Thunb) Matsun8 Nakai seeds under temperature and osmotic stress. Seed Sci. Technol. 27:871-875.

Ellis, R. H. and E. H. Roberts (1980). Towards a rational basis for testing seed quality, pp. 605-635. In: Hebblethwaite, P. D. (Eds.). Seed Production. Butterworths, London.

Finch-Savage, W. E., L. Dent and J. Clark (2004). Soak condition and temperature following sowing influence the response of maize(Zea Mays L.) seeds to on-farm priming (pre-sowing seed soak). Field Crops Res. 90:361-374.

First National Forage Crops Congress of Iran (2005). Faculty of Agronomy and Animal Science of Tehran of Tehran Agriculture and Natural resources University.

Giri, G. S. and W. F. Schilinger (2003). Seed priming winter wheat for germination, emergence, and yield. Crop Sci. 43:2135-2141.

Harris, D., A. K. Pathan, P. Gothkar, A. Joshi, W. Chivasa and Nyamudeza (2001). On-farm seed priming:using participatory methods to revive and refine key technology. Agric. Sys. 69:151-164.

Heydecker, W. and P. Coolbaer (1977). Seed treatments for improved performance survey and attempted prognosis. Seed Sci. Technol. 5:353-425.

ISTA, 1996. Rules for Seed Testing. International Seed Testing Association. 1996. Seed Sci. Technol. Zurich, Switzerland.

Kaya, M. D., O. Gamze, M. Atal, C. Yakup, K. Ozer (2006). Seed treatments to overcome salt and drought stress during germination in sunflower (Helianthus annuus L.). Europ. J.Agron. 24:291-295.

Khajeh-Hosseini, M., A. A. Powell and I. J. Bingham (2003). The interaction between salinity stress and seed vigour during germination of soybean seeds. Seed Sci. Technol. 31:715-725.

Khoshgoftar,B. (1992). Bersim Clover. Publication of agriculture extention organization of Mazandaran province.

Korkmaz, A. (2006). Ameliorative effects of ethylene precursor and polyamines on the high temperature inhibition of seed germination in lettuce (Lactuca sativa L.) before and after seed storage. Seed Sci. Technol. 34:465-474.
Mehra, V., J. Tripathi and A. A. Powell (2003). Aerated hydration treatment improves the response of Brassica juncea and Brassica campestris seeds to stress during germination. Seed Sci. Technol. 31:57-70.

Michel, B. E. (1983). Evaluation of the water potentials of solutions of polyethylene glycol 8000 both in the absence and presence of other solutes. Plant Physiol. 72:66-70.

Michel, B. E. and M. R. Kaufmann (1973). The osmotic potential of polyethylene glycol 6000. Plant Physiol. 51:914-916.

Misra, N. M. and D. P. Dwivedi (1980). Effect of pre-sowing seed treatment on growth and dry-matter accumulation of high-yielding wheat under rainfall conditions. Indian J. Agron. 25:230-234.

Moosavi, S. A., R. T. Afshari, F. Sharifzadeh and A. Aynehband (2009). Effect of seed priming on germination characteristics, polyphenoloxidase, and peroxidase activities of four amaranth cultivars. Journal of Food, Agriculture and Environment 7 (3-4):353-358 .

Musavi Aghdam, H. (1985). Recognizing different variety of clover and thereimportance for producingforage. Publication of techniqal office forests and pastures organization.

Nascimento, W. M. and F. A. S. Arago (2004). Muskmelon seed priming in relation to seed vigour. Science Agric. 61:114117.

Ozbingol, N., F. Corbineau and D. Come (1998). Response of tomato seeds to osmoconditioning as related to temperature and oxygen. Seed Sci. Res. 8:377-384.

Pill, W. G. (1995). Low water potential and pre-sowing germination treatments to improve seed quality, pp. 319359. In: Basra, A. S. (Eds.). Seed Quality. Food Products Press, New York, NY, USA.

Stofella, P. J., D. P. Lipucci, A. Pardossi and F. Tognoni (1992). Seedling root morphology and shoot growth after seed priming or pregermination of bell pepper. Hortsci. 27: 214214-215.

Shrestha, A., O. B Hesterman, J. M.Squire, J. W. Fisk and C. C. Sheaffer (1996). Annual medics and bersim clover as emergency forage. Agron J. 90:197-201.

Still, D., P. Dahal and K. Bradford (1997). A single-seed assay for endo- $\beta$-mannanase activity from tomato endosperm and radicle tissues. Plant Physiol. 113:13-20.

Subedi, K. D. and B. L. Ma (2005). Seed priming dose not improve corn yield in a humid temperate environment. Agron J. 97:211-218.

Zarrineh, H. and H. Akhavan (1985). Another investigating toward Bersim Clover as the second rotation after rice in Mazandaran province. Publication of agriculture organization of Mazandaran province.

www. Dfid.psp.org. 